\title{
Pengaruh Interpersonal Needs dan Simtom Depresi Terhadap Ide Bunuh Diri
}

\section{Tri Hariyono}

Universitas Islam Negeri Syarif Hidayatullah Jakarta, Indonesia

hariyonotri15@gmail.com

\begin{abstract}
This study aimed at determining the effect of interpersonal needs and symptoms of depression on the idea of suicide in the community of Gunungkidul Regency. For statistical calculations, researchers used LISREL 8.70 and SPSS 18.0. The results showed that interpersonal needs and depressive symptom variables had a significant influence on the idea of suicide in Gunungkidul District by contributing $22 \%$. However, seen from the coefficient table, there were only three variables that had a significant influence on the idea of suicide, namely the dimensions of cognitive depression symptoms, gender and smoking behavior with $p$-value $<0.05$. Whereas the variable perceived burdensomeness, including belongingness, cognitive depression symptoms, motivational depression symptoms, physical depression symptoms, education level and alcohol consumption behavior did not significantly influence suicidal ideation.
\end{abstract}

Keywords: Interpersonal Needs, Depressive Symptoms, Suicidal Ideas

\begin{abstract}
Abstrak
Penelitian ini bertujuan untuk mengetahui pengaruh interpersonal needs dan simtom depresi terhadap ide bunuh diri masyarakat Kabupaten Gunungkidul. Untuk penghitungan statistik, peneliti menggunakan LISREL 8.70 serta SPSS 18.0. Hasil penelitian menunjukkan bahwa variabel interpersonal needs dan simtom depresi memberikan pengaruh yang signifikan terhadap ide bunuh diri masyarakat Kabupaten Gunungkidul dengan memberikan kontribusi sebesar $22 \%$. Namun dilihat dari tabel koefisien, hanya terdapat tiga variabel yang berpengaruh signifikan terhaddap ide bunuh diri, yaitu dimensi simtom depresi kognitif, jenis kelamin dan perilaku merokok dengan p-value $<0.05$. sedangkan variabel perceived burdensomeness, thwarted belongingness, simtom depresi kognittif, simtom depresi motivasional, simtom depresi fisik, tingkat pendidikan serta perilaku mengkonsumsi alkohol tidak memberikan pengaruh signifikan terhadap ide bunuh diri.
\end{abstract}

Kata kunci: Interpersonal Needs, Simtom Depresi, Ide Bunuh Diri 


\section{Pendahuluan}

Dalam kasus percobaan bunuh diri maupun kematian karena bunuh diri prediktor yang paling kuat adalah ide bunuh diri (Mann dalam Wong, Tran, Koo, Kelly Chiu, Yu-Chen, Mok, Yvone, 2011). Penelitian terdahulu mengatakan bahwa ide bunuh diri berhubungan dengan beberapa faktor yang potensial seperti depresi (Wong, et al 2011; Chan, Liu, Chau, Chan, 2011; Sugawara, Yasui-Fukukori, Sasaki, Danjo, Matsuzaka, Kaneko, Nakaji, 2012; Lemstra, Rogers, Morarors, Grants 2013), Interpersonal needs (Joiner, 2005; Wong, et al, 2011), perbedaan jenis kelamin (Sugawara, et al, 2012), perilaku merokok (McGee, Williams, Nada-Raja, 2005; Sugawara, et al, 2012), serta perilaku mengkonsumsi alkohol (Sugiwara, et al, 2012)

Van Orden, Witte, Cukrowicz, Braithwaite, Selby, Joiner (2010) mencatat beberapa studi tentang faktor yang diduga mempengaruhi risiko bunuh diri. Ada enam faktor yang sudah diteliti lebih dari lima belas kali. Satu yang paling kuat dan reliabel adalah isolasi sosial. Dari hal tersebut, studinya mengajukan isolasi sosial dapat diasosiasikan dengan bunuh diri karena merupakan indikator yang dapat terobservasi dari kebutuhan fundamental manusia yang tidak terpenuhi. Kebutuhan ini dijelaskan oleh Baumeister (Van Orden, et al. 2010) sebagai "kebutuhan untuk memiliki".

Sugawara, et al (2012) dalam penelitiannya menyatakan bahwa tingkat ide bunuh diri berbeda untuk tiap jenis kelamin. Tercatat bahwa laki-laki memiliki intensitas lebih tinggi dalam kemunculan ide bunuh diri dari perempuan. Hal ini berbanding terbalik dengan penelitian Lemstra, et al (2013) yang menyatakan bahwa prevalensi ide bunuh diri perempuan lebih tinggi dari laki-laki. 
Gaya hidup juga menjadi penyebab munculnya ide bunuh diri. 43.2\% perokok pernah memiliki ide bunuh diri bila dibandingkan dengan $15.2 \%$ orang yang tidak merokok. Kemudian $41 \%$ pengkonsumsi alkohol pernah mengalami kemunculan ide bunuh diri dibandingkan dengan orang yang tidak mengkonsumsi alkohol yang hanya $28 \%$ dari mereka mengalami kemunculan ide bunuh diri (Lemstra, et al, 2013).

Berdasarkan uraian, maka peneliti akan mengkaji secara mendalam pada penelitian ini mengenai "Pengaruh Interpersonal Needs dan Simtom Depresi terhadap Ide Bunuh Diri pada Masyarakat Kabupaten Gunungkidul”.

\section{Ide Bunuh Diri}

Van Orden, et al (2011) dalam penelitiannya mengatakan bahwa bunuh diri merupakan percobaan bunuh diri yang berhasil. Jadi, bunuh diri bukan merupakan sebuah kejadian yang kebetulan. Peristiwa bunuh diri merupakan hasil dari sebuah pemikiran, gagasan atau ide untuk bunuh diri. Hal ini didasarkan pada term bunuh diri yang merupakan hasil dari percobaan bunuh diri yang berakibat pada kematian.

Joiner, Steer, Brown, Beck, Pettit, dan Rudd (2003) mengatakan bahwa ide bunuh diri merupakan ekspresi yang luas dari keinginan untuk mati sampai kepada perencanaan detail untuk melakukan ide bunuh diri.

\section{Interpersonal Needs}

Joiner (2005) mengatakan bahwa interpersonal needs merupakan pernyataan interpersonal yang negatif dari diri seseorang yang terdiri dari dua dimensi. Dimensi yang pertama adalah perceived burdensomeness yaitu pernyataan bahwa diri seseorang memberatkan 
kehidupan orang lain, kemudian yang kedua adalah thwarted belongingness yaitu pernyataan bahwa dirinya merasa terasing dan sendirian dalam menjalani kehidupan. Joiner dalam Wong, et al, (2011) mengemukakan bahwa ide untuk bunuh diri didasarkan kepada dua pernyataan interpersonal yang negatif tersebut.

\section{Simtom Depresi}

Term depresi kadang digunakan untuk menunjukkan pola kompeks dari penyimpangan perasaan, kognisi dan kebiasaan, sarta tidak direpresentasikan atas gangguan psikiatris diskrit (Beck, 1967). Ciri umum depresi adalah perasaan sedih, kosong, mood yang berubahubah, dilengkapi dengan perubahan somatis atau kognitif yang secara signifikan mempengaruhi kapasitas individu atas fungsi tubuhnya (DSMV, 2013). Menurut Beck (1967), Depresi merupakan kondisi abnormal individu yang termanifestasi sebagai tanda dan gejala seperti menurunnya mood, meningkatnya sikap pesimis, kehilangan spontanitas dan tanda-tanda fisik yang lain.

\section{Metodologi Penelitian}

Penelitian ini menggunakan teknik non-probability sampling. Populasi penelitian ini adalah Masyarakat Kabupaten Gunungkidul, dimana jumlah sampelnya adalah 167 orang. Penelitian ini menggunakan tiga skala, yaitu: (1) Ide Bunuh Diri, menggunakan skala Modified Scale for Suicide Ideation yang diadaptasi oleh Ivan Miller (1991) berdasarkan Scale for Suicide Ideation yang dikembangkan oleh Aaron Beck (1979) yang terdiri atas 18 item wawancara mengenai ide bunuh diri aktif dan pasif. (2) Interpersonal Needs, menggunakan skala Interpersonal Needs Questionnaire yang terdiri dari 25 item skala likert 
yang mengukur dimensi perceived burdensomeness dan thwarted belongingness. Skala ini diadaptasi dari alat ukur yang dikembangkan oleh Thomas Joiner (2005). (3) Simtom Depresi, skala Beck Depression Inventory II mengukur simtom depresi emosional, kognitif, motivasional, serta simtom depresi fisik yang terdiri atas 21 item skala likert. Skala ini merupakan adaptasi dari skala baku yang dikembangkan oleh Beck (1969).

Untuk menjawab pertanyaan penelitian, digunakan teknik analisis regresi berganda. Teknik ini digunakan untuk menentukan ketapatan prediksi serta mengetahui besarnya pengaruh dari variabel independen terhadap variabel dependen. Regresi berganda merupakan metode statistika yang dipergunakan untuk membentuk model pengaruh antara satu variabel dependen dengan lebih dari satu variabel independen. Analisis statistik dilakukan dengan bantuan software Lisrel 8.70 dan SPSS 17.0.

Untuk menilai apakah model regresi yang dihasilkan merupakan model yang paling sesuai atau tidak, dibutuhkan beberapa pengujian dan analisis sebagai berikut:

\section{$\mathbf{R}^{2}$ (koefisien determinasi berganda)}

$\mathrm{R}^{2}$ menunjukkan variasi atau perubahan variabel dependen yang disebabkan variabel independen atau digunakan untuk mengetahui besarnya hubungan variabel independen dengan variabel dependen. Untuk mendapatkan nilai $\mathrm{R}^{2}$ digunakan persamaan sebagai berikut:

$$
\mathrm{R}^{2}=\frac{\text { jumlah kuadrat regresi }}{\text { jumlah kuadrat } \mathrm{y} \text { total }}=\frac{\text { SSreg }}{S S y}
$$


Uji F

Untuk membuktikan apakah pengaruh variabel independen terhadap variabel signifikan atau tidak. Maka digunakan uji F. Dari hasil uji F yang dilakukan nantinya, dapat dilihat apakah beberapa variabel independen yang diujikan memiliki hubungan dengan dependen variabel. Untuk membuktikan hal tersebut digunakan persamaan sebagai berikut:

$$
\mathrm{F}=\frac{R 2 / k}{(1-R 2) /(n-k-1)}
$$

Dari hasil uji F yang dilakukan nantinya akan dapat dilihat apakah variabel independen yang diujikan memiliku pengaruh terhadap variabel independen. Penghitungan penelitian ini dilakukan dengan menggunakan software SPSS 18.0

\section{Hasil Penelitian dan Pembahasan}

Dari hasil penghitungan, terlihat $\mathrm{R}^{2}$ adalah $22 \%$ artinya, bervariasinya variabel dependen dipengaruhi oleh bervariasinya variabel independen yang diteliti pada penelitian ini. Sedangkan 78\% lainnya dipengaruhi oleh variabel diluar penelitian ini.

Tabel 1. R Square

\begin{tabular}{|c|c|c|c|c|}
\hline \multicolumn{5}{|c|}{ Model Summary ${ }^{b}$} \\
\hline Model & $\mathrm{R}$ & R Square & Adjusted R Square & Std. Error of the Estimate \\
\hline 1 & $.469^{a}$ & .220 & .154 & 9.09780 \\
\hline
\end{tabular}

Selanjutnya adalah dengan melihat tabel koefisien regresinya untuk mengetahui variabel independen mana saja yang diuji dan memiliki pengaruh yang signifikan ataupun tidak terhadap variabel dependen. 
Tabel 2. Koefisien Regresi

Coefficients $^{a}$

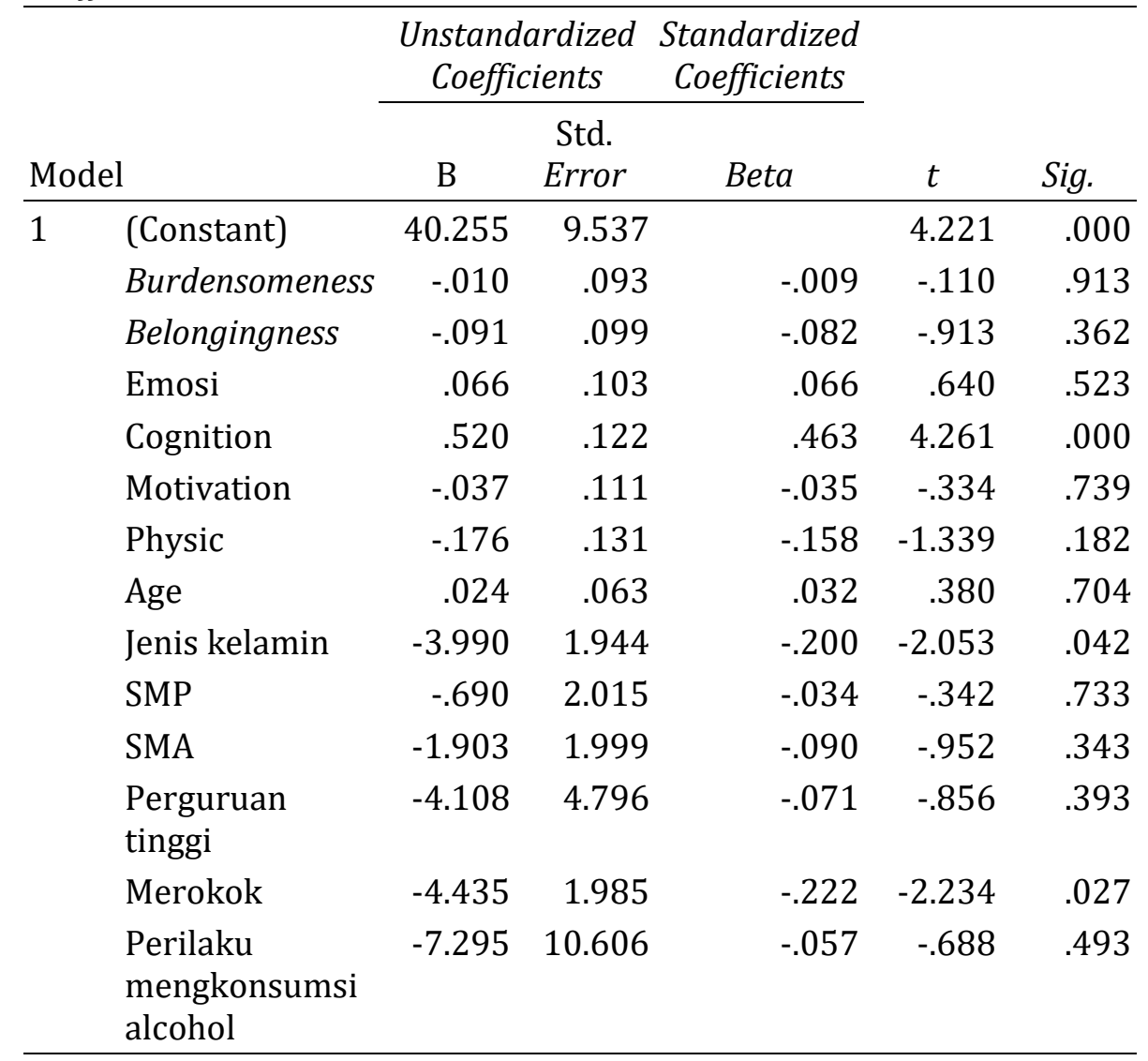

Berdasarkan tabel 2 terlihat dimensi simtom depresi kognisi, jenis kelamin, serta perilaku merokok memiliki pengaruh yang signifikan terhadap ide bunuh diri. sedangkan dimensi lainnya tidak memiliki pengaruh yang signifikan terhadap ide bunuh diri. Dengan demikian dapat disusun persamaan regresi pada ide bunuh diri. yaitu, Ide bunuh diri $=40.225-0.010$ preceived Burdensomeness - 0.091 thwarted Belongingness +0.066 simtom emosi +0.520 simtom kognisi -0.037 simtom motivasional -0.176 simtom fisik +0.024 usia -3.990 Jenis kelamin - 0.690 SMP - 1.903 SMA - 4.108 Perguruan tinggi - 4.435 Perilaku merokok - 7.295 Perilaku mengkonsumsi alkohol 
Penelitian ini merupakan usaha untuk lebih memahami konteks variabel internal yang ada dalam diri individu masyarakat dalam mempengaruhi ide bunuh diri. hasil utama dalam penelitian ini yaitu didapatkan bahwa hipotesis penelitian (Ha) diterima sehingga terdapat pengaruh yang signifikan antara interpersonal needs dan simtom depresi terhadap ide bunuh diri pada masyarakat Kabupaten Gunungkidul. Hal ini sejalan dengan penelitian oleh Wong (2010) yang menemukan hubungan yang signifikan antara simtom depresi dengan ide bunuh diri. Sejalan dengan penelitian, bahwa simtom depresi dengan empat dimensinya memiliki pengaruh munculnya ide bunuh diri, namun hanya simtom kognisi saja yang mempengaruhi ide bunuh diri secara signifikan.

Simtom depresi kognisi secara signifikan memiliki pengaruh signifikan terhadap ide bunuh diri. Pada simtom depresi kognisi para penderita memiliki pemikiran negatif, cenderung diliputi rasa bersalah serta layak untuk dihukum. Hal ini berlanjut dengan anggapan peristiwa negatif yang dialaminya akan berlanjut atau bahkan bertambah buruk (Beck, 1967).

Sejalan dengan data pelaku bunuh diri, variabel demografi jenis kelamin memiliki pengaruh signifikan terhadap ide bunuh diri. Peneliti membandingkan hasil penelitian dengan data dari Kepolisian Resor Gunungkidul tentang kasus bunuh diri dalam rentang 2012-2014 melihat bahwa laki-laki memiliki ide bunuh diri lebih tinggi sehingga memiliki kecenderungan lebih tinggi untuk melakukan bunuh diri. Peneliti menilai kemungkinan laki-laki memiliki tanggung jawab yang lebih tinggi dari perempuan, sehingga lebih rentan dalam menderita gangguan depresi (terutama simtom depresi kognisi). 
Sejalan dengan penelitian Sugawara, et al (2012), Lemstra, et al (2013) dan Chan, et al (2011) yang menyatakan bahwa ada perbedaan tingkat ide bunuh diri pada laki-laki serta perempuan. Menurut penelitian tersebut status pernikahan, pekerjaan, serta jenis kelamin berpengaruh terhadap simtom depresi dan ide bunuh diri.

Variabel demografi perilaku merokok memiliki pengaruh yang signifikan. Hal ini sejalan dengan penelitian McGee, et al (2005) dan Chan, et al (2011) yang menyatakan bahwa merokok ikut mempengaruhi ide bunuh diri.

\section{Hasil Penelitian dan Pembahasan}

\section{Deskripsi Statistik Masing-masing Variabel Penelitian}

Data skor Ide bunuh diri, interpersonal needs, simtom depresi serta jenis kelamin dan usia diperoleh melalui angket yang disebar kepada anggota masyarakat Kabupaten Gunungkidul disajikan dalam tabel 4.6 berikut:

Tabel 4.6.

\begin{tabular}{lrrrrr}
\hline \multicolumn{5}{c}{ Deskripsi Statistik Variabel Penelitian Descriptive Statistics } \\
\hline & $\mathrm{N}$ & Minimum & Maximum & Mean & \multicolumn{1}{c}{$\begin{array}{c}\text { Std. } \\
\text { Deviation }\end{array}$} \\
\hline Suicide & 167 & 47.17 & 124.62 & 50.0000 & 9.88838 \\
Burdensomeness & 167 & 18.87 & 68.81 & 50.0000 & 9.10941 \\
Belongingness & 167 & 27.37 & 66.94 & 50.0000 & 8.96130 \\
Emosi & 167 & 43.47 & 86.27 & 50.0000 & 10.00000 \\
Cognition & 167 & 43.65 & 82.83 & 50.0000 & 8.80788 \\
Motivation & 167 & 45.93 & 89.61 & 50.0000 & 9.26715 \\
Physic & 167 & 42.66 & 87.45 & 50.0000 & 8.86887 \\
Age & 167 & 15.00 & 80.00 & 32.5329 & 13.23094 \\
Valid N (listwise) & 167 & & & & \\
\hline
\end{tabular}

Berdasarkan tabel, dapat diketahui jumlah subjek penelitian sebanyak 167 orang dengan skor dimensi ide bunuh diri terendah adalah 
Tri Hariyono

47.17 sedangkan skor tertinggi adalah 124.62. kemudian skor dimensi perceived burdensomeness terendah adalah 18.87 sedangkan skor tertinggi adalah 68.81. skor dimensi thwarted belongingness terendah adalah 27.37 sedangkan skor tertinggi adalah 66.94. skor dimensi simtom emosi terendah adalah 43.47 sedangkan skor tertinggi 86.27. skor dimensi simtom kognisi terendah adalah 43.65 sedangkan skor tertinggi adalah 82.83. skor dimensi simtom motivasi terendah adalah 45.93 sedangkan skor tertinggi 89.61. skor dimensi simtom fisik terendah adalah 42.66 sedangkan skor tertinggi adalah 87.45. skor dimensi usia terendah adalah 15.00 sedangkan skor tertinggi adalah 80.00 .

Tabel 4.7. Norma skor

\begin{tabular}{ccc}
\hline Norma & Rentang & Intepretasi \\
\hline $\mathrm{X}<$ Mean & $<50$ & Rendah \\
$\mathrm{X} \geq$ Mean & $\geq 50$ & Tinggi \\
\hline
\end{tabular}

Setelah kategori tersebut didapatkan, maka akan diperoleh nilai persentasi kategori untuk ide bunuh diri, interpersonal needs, simtom depresi, usia masyarakat Kabupaten Gunungkidul.

\section{Kategorisasi Skor Variabel Penelitian Kategorisasi Tingkat Ide Bunuh Diri}

Di bawah ini disajikan tabel yang menunjukkan sebaran variabel ide bunuh diri yang dibagi menjadi dua kategori sebagaimana telah dijelaskan sebelumnya, yaitu tinggi dan rendah.

Tabel 4.8. Kategorisasi Tingkat Ide Bunuh diri Ide Bunuh Diri 


\begin{tabular}{rlrrrr}
\hline & & & \multicolumn{2}{c}{ Cumulative } \\
\multirow{4}{*}{ Valid } & Frequency & Percent & Valid Percent & Percent \\
& Rendah & 152 & 91.0 & 91.0 & 91.0 \\
& Tinggi & 15 & 9.0 & 9.0 & 100.0 \\
& Total & 167 & 100.0 & 100.0 & \\
\hline
\end{tabular}

Berdasarkan tabel 4.4, ditemukan bahwa 9\% dari total responden memiliki tingkat ide bunuh diri tinggi dan 91\% memiliki tingkat ide bunuh diri rendah. Dapat disimpulkan bahwa dari keseluruhan responden yang diteliti, tingkat ide bunuh diri yang paling dominan berada di kategori rendah.

\section{Kategorisasi Tingkat Interpersonal Needs}

Selanjutnya dibawah ini disajikan tabel yang menunjukkan sebaran kategorisasi tingkat interpersonal needs.

Tabel 4.9. Kategorisasi Intepersonal Needs

\begin{tabular}{ccccc}
\hline Dimensi & & Frequency & Percent & Valid Percent \\
\hline \multirow{2}{*}{ Perceived burdensomeness } & Rendah & 80 & 47.9 & 47.9 \\
& Tinggi & 87 & 52.1 & 100 \\
Thwarted Belongingness & Rendah & 102 & 61.1 & 61.1 \\
& Tinggi & 65 & 38.9 & 100 \\
\hline
\end{tabular}

Dari tabel, ditemukan bahwa $52.1 \%$ dari total responden memiliki perceived burdensomeness yang tinggi dan $47.9 \%$ responden memiliki tingkat perceived burdensomeness yang rendah.

Ditemukan pula 38.9\% dari total responden memiliki tingkat thwarted belongingness yang tinggi dan $61.1 \%$ responden memiliki tingkat thwarted belongingness yang rendah. 
Tri Hariyono

\section{Kategorisasi Tingkat Simtom Depresi}

Di bawah ini disajikan tabel yang menunjukkan sebaran kategorisasi tingkat simtom depresi.

Tabel 4.10. Kategorisasi Simtom Depresi

\begin{tabular}{lcccc}
\hline \multicolumn{1}{c}{ Dimensi } & & Frequency & Percent & Valid Percent \\
\hline Simtom Emosi & Rendah & 119 & 71.3 & 71.3 \\
& Tinggi & 48 & 28.7 & 100 \\
Simtom Kognisi & Rendah & 107 & 64.1 & 64.1 \\
& Tinggi & 60 & 35.9 & 100 \\
Simtom Motivasional & Rendah & 136 & 81.4 & 81.4 \\
& Tinggi & 31 & 18.6 & 100 \\
Simtom Fisik & Rendah & 94 & 56.3 & 56.3 \\
& Tinggi & 73 & 43.7 & 100 \\
\hline
\end{tabular}

Dari tabel, ditemukan bahwa $28.7 \%$ dari total responden memiliki tingkat simtom emosi yang tinggi dan $71.3 \%$ responden memiliki simtom emosi yang rendah. Ditemukan pula 35.9\% dari total responden memiliki tingkat simtom kognisi yang tinggi, sedangkan $64.1 \%$ responden memiliki tingkat simtom kognisi yang rendah.

Ditemukan $18.6 \%$ dari total responden memiliki tingkat simtom motivasi yang tinggi, sedangkan $81.4 \%$ responden memiliki tingkat simtom motivasi yang rendah. Ditemukan pula $43.7 \%$ dari total responden memiliki tingkat simtom fisik yang tinggi, sedangkan $56.3 \%$ responden memiliki tingkat simtom fisik yang rendah.

\section{Pengujian Proporsi Varians Masing-masing Independent Variable}

Selanjutnya, peneliti memuat informasi mengenai proporsi varian. Pengujian pada tahapan ini bertujuan untuk mengetahui bagaimana penambahan proporsi varian dari masing-masing independent variable dan variabel demografi terhadap ide bunuh diri. pada tabel 4.14 kolom pertama adalah penambahan varian dependent 
Tri Hariyono

variable dari tiap independent variable dan variabel demografi yang dianalisis satu per satu tersebut. Kolom kedua merupakan nilai murni varians dependent variable dari tiap independent variable dan variabel demografi yang dimasukkan secara satu per satu, kolom ketiga adalah nilai $\mathrm{F}$ hitung bagi independent variable dan variabel demografi yang bersangkutan, kolom DF adalah derajat bebas bagi independent variable dan variabel demografi yang bersangkutan pula, yang terdiri dari numerator dan denumerator, kolom $\mathrm{F}$ tabel adalah kolom mengenai nilai independent variable dan variabel demografi pada tabel $\mathrm{F}$ dengan $\mathrm{DF}$ yang telah ditentukan sebelumnya, nilai kolom inilah yang akan dibandingkan dengan kolom nilai $\mathrm{F}$ hitung. Apabila nilai $\mathrm{F}$ hitung lebih besar daripada F tabel, maka kolom selanjutnya yaitu kolom signifikansi yang akan dituliskan signifikan dan sebaliknya. Besarnya proposi varians pada ide bunuh diri dapat dilihat pada tabel 4.14 dan tabel 4.15

Tabel 4.14.

Kontribusi Varians Independent Variable terhadap Dependent Variable I

\begin{tabular}{lcccccr}
\hline \multicolumn{7}{c}{ Model Summary } \\
\hline Model & $\mathrm{R}$ & \multicolumn{5}{c}{ Change Statistics } \\
\cline { 3 - 7 } & Square & R Square Change & F Change & $\mathrm{df1}$ & $\mathrm{df} 2$ & Sig. F Change \\
1 & .012 & .012 & 1.954 & 1 & 165 & .164 \\
2 & .014 & .002 & .396 & 1 & 164 & .530 \\
3 & .086 & .072 & 12.831 & 1 & 163 & .000 \\
4 & .158 & .072 & 13.946 & 1 & 162 & .000 \\
5 & .159 & .001 & .170 & 1 & 161 & .680 \\
6 & .177 & .018 & 3.414 & 1 & 160 & .066 \\
7 & .178 & .001 & .235 & 1 & 159 & .628 \\
8 & .180 & .002 & .389 & 1 & 158 & .534
\end{tabular}


1. Predictors in the Model: (Constant), Burdensomeness

2. Predictors in the Model: (Constant), Burdensomeness, Belongingness

3. Predictors in the Model: (Constant), Burdensomeness, Belongingness, Emosi

4. Predictors in the Model: (Constant), Burdensomeness, Belongingness, Emosi, Cognition

5. Predictors in the Model: (Constant), Burdensomeness, Belongingness, Emosi, Cognition, Motivation

6. Predictors in the Model: (Constant), Burdensomeness, Belongingness, Emosi, Cognition, Motivation, Physic

7. Predictors: (Constant), Burdensomeness, Belongingness, Emosi, Cognition, Motivation, Physic, Age

8. Predictors: (Constant), Burdensomeness, Belongingness, Emosi, Cognition, Motivation, Physic, Age, females

Dari tabel, dapat disampaikan informasi sebagai berikut: (1) Variabel perceived burdensomeness memberikan sumbangan sebesar $1.2 \%$ dalam varians Interpersonal needs. Sumbangan tersebut tidak signifikan secara statistik dengan $\mathrm{F}=0.164$ dan $\mathrm{df}=1,165$ ( $\operatorname{sig}>0.05)$. (2) Variabel thwarted belongingness memberikan sumbangan sebesar $0.2 \%$ dalam varians Interpersonal needs. Sumbangan tersebut tidak signifikan secara statistik dengan $\mathrm{F}=0.530$ dan $\mathrm{df}=1,164(\mathrm{sig}>0.05)$. (3) Variabel simtom emosi memberikan sumbangan sebesar $7.2 \%$ dalam varians simtom depresi. Sumbangan tersebut signifikan secara statistik dengan $\mathrm{F}=0.000 \mathrm{dan} \mathrm{df}=1,163(\mathrm{sig}<0.05)$. (4) Variabel simtom kognisi memberikan sumbangan sebesar $7.2 \%$ dalam varians simtom depresi. Sumbangan tersebut signifikan secara statistik dengan $\mathrm{F}=0.000 \mathrm{dan} \mathrm{df}=$ 
Tri Hariyono

1,162 (sig < 0.05). (5) Variabel simtom motivasi memberikan sumbangan sebesar $0.1 \%$ dalam varian simtom depresi. Sumbangan tersebut tidak signifikan secara statistik dengan $\mathrm{F}=0.680$ dan $\mathrm{df}=1,161$ (sig > 0.05). (6) Variabel simtom fisik memberikan sumbangan sebesar $1.8 \%$ dalam varians simtom depresi. Sumbangan tersebut tidak signifikan secara statistik dengan $\mathrm{F}=0.066$ dan $\mathrm{df}=1,160(\mathrm{sig}>0.05)$. (7) Variabel usia memberikan sumbangan sebesar $0.1 \%$ dalam varian usia. Sumbangan tersebut tidak signifikan secara statistik dengan $\mathrm{F}=$ 0.628 dan $\mathrm{df}=1,159$ (sig $>0.05)$. (7) Variabel females memberikan sumbangan sebesar $0.1 \%$ dalam varians jenis kelamin. Sumbangan tersebut tidak signifikan secara statistik dengan $\mathrm{F}=0.746 \mathrm{dan} \mathrm{df}=1,165$ $(\operatorname{sig}>0.05)$.

Tabel 4.15

Kontribusi Varians Variabel Demografi terhadap Dependent Variable II Model Summary

Model

Change Statistics

$$
\text { df }
$$

R Square R Square Change F Change 1 df2 Sig. F Change

$\begin{array}{rrrrrrr}1 & .013 & .013 & 2.182 & 1 & 165 & .142 \\ 2 & .015 & .002 & .252 & 1 & 164 & .617 \\ 3 & .017 & .002 & .325 & 1 & 163 & .569 \\ 4 & .034 & .018 & 2.936 & 1 & 162 & .089 \\ 5 & .034 & .000 & .034 & 1 & 161 & .854\end{array}$

1. Predictors: (Constant), , SMP

2. Predictors: (Constant), , SMP, SMA

3. Predictors: (Constant), , SMP, SMA, Perguruan tinggi

4. Predictors: (Constant), , SMP, SMA, Perguruan tinggi, Merokok 
Tri Hariyono

5. Predictors: (Constant), , SMP, SMA, Perguruan tinggi, Merokok, Perilaku mengkonsumsi alkohol

Dari tabel, dapat disampaikan informasi sebagai berikut:(1) Variabel demografi SMP memberikan sumbangan sebesar $1.3 \%$ dalam varian tingkat pendidikan. Sumbangan tersebut tidak signifikan secara statistik dengan $\mathrm{F}=0.142 \mathrm{dan} \mathrm{df}=1,165$ ( $\mathrm{sig}>0.05$ ). (2) Variabel demografi SMA memberikan sumbangan sebesar 0.2\% dalam varian tingkat pendidikan. Sumbangan tersebut tidak signifikan secara statistik dengan $\mathrm{F}=0.617$ dan $\mathrm{df}=1,164(\mathrm{sig}>0.05)$. (3) Variabel demografi perguruan tinggi memberikan sumbangan sebesar $0.2 \%$ dalam varian tingkat pendidikan. Sumbangan tersebut tidak signifikan secara statistik dengan $\mathrm{F}=0.569$ dan $\mathrm{df}=1,163$ (sig > 0.05). (4) Variabel perilaku merokok memberikan sumbangan sebesar 3.9\% dalam varians merokok. Sumbangan tersebut signifikan secara statistik dengan $\mathrm{F}=0.089 \mathrm{dan} \mathrm{df}=$ 1,162 (sig > 0.05). (5) Variabel erilaku mengkonsumsi alkohol memberikan sumbangan sebesar $0 \%$ dalam varians perilaku mengkonsumsi alkohol. Sumbangan tersebut tidak signifikan secara statistik dengan $\mathrm{F}=0.854$ dan $\mathrm{df}=1,161$ ( $\mathrm{sig}>0.05)$.

\section{Simpulan}

Berdasarkan hasil analisis data dan pengujian hipotesis yang telah dikemukakan sebelumnya, adapun kesimpulan yang dapat diambil dari penelitian ini adalah: (1) Terdapat pengaruh yang signifikan interpersonal needs dan simtom depresi terhadap ide bunuh diri pada masyarakat Kabupaten Gunungkidul. (2) Ide bunuh diri dipengaruhi secara signifikan oleh dimensi simtom depresi kognitif. Hal ini menandakan bahwa semakin tinggi tingkat simtom depresi kognitif seseorang, maka semakin tinggi pula ide bunuh dirinya. (3) Tidak ada 
Tri Hariyono

pengaruh signifikan dari dimensi perceived burdensomeness, dan dimensi thwarted belongingness terhadap ide bunuh diri. (4) Tidak ada pengaruh signifikan dimensi simtom depresi emosi, simtom depresi motivasional, dan simtom depresi fisik terhadap ide bunuh diri. (5) Variabel demografi jenis kelamin memiliki pengaruh signifikan terhadap ide bunuh diri, dimana ada perbedaan rata-rata ide bunuh diri antara kelompok jenis kelamin laki-laki dengan kelompok jenis kelamin perempuan. (6) Tidak ada pengaruh signifikan variabel demografi tingkat pendidikan dan alkoholik terhadap ide bunuh diri. (7) Variabel demografi perilaku merokok memiliki pengaruh signifikan terhadap ide bunuh diri, dimana ada perbedaan rata-rata ide bunuh diri antara kelompok perilaku merokok dan bukan kelompok perilaku merokok. Jadi, ide bunuh diri dipengaruhi secara signifikan oleh simtom kognisi, jenis kelamin, serta perilaku merokok.

\section{Daftar Pustaka}

Adriani, Y., \& Hasan, R. 2009. Psikologi abnormal \& psikopatologi. Jakarta: Fakultas Psikologi UIN Syarif Hidayatullah.

American Psycological Association. 2013. Diagnosis and statistical manual of mental health 5th edition. Arlington: American Psychological Association.

Badan Pusat Statistik. 2010. Sensus penduduk Indonesia http://bps.go.id/ Beck, Aaron. 1967. Depression. University of Pennsylvania Press Brown, Gregory K. 2001. A review of suicide assessment Measures for intervention research with adults and older adults. Pensylvania: University of Pensylvania 
Center for Drug Evaluation and Research. 2012. Guidance for industry; suicidal ideation and behavior: U.S Department of Health and Human Services

Chan, Hsian-Lin., Liu, Chia-Yih. et al. 2011. Prevalences and association of suicide ideation among Taiwanese elderly-A population-based cross-sectional study. Chang Gung Medical Journal 2011;34: 197204.

Darmaningtyas. 2002. Pulung gantung: menyingkap tragedi bunuh diri di Kabupaten Gunungkidul. Yogyakarta: Salwa Press

Davidson, G.C., Neale, J.M., \& Kring, A.M. 2004. Abnormal psychologies Psikologi abnormal (edisi kesembilan). Noermalasari Fajar (terj,). Jakarta: Raja Grafindo.

Durkheim, Emile. 1951. Suicide: a study in sociology. London: The Free Press.

Fitrianatsany. 2013. Motif sosial tindak bunuh diri di Desa Wonorejo Srengat Blitar. Skripsi Fakultas Ushuludin UIN Sunan Kalijaga Yogyakarta.

Joiner, T., Steer, R. et al. 2003. Worst-point suicidal plans: A dimension of suicidality predictive of past suicide attempts and eventual death by suicide. Behaviour research \& therapy. 41, 1469-1480.

Joiner, Thomas. 2005. Why people die by suicide. Florida: Harvard.

Kaplan, H.D., Sadock, B.J., \& Grebb, J.A. 1996. Psychiatric synopsys: Clinical psychiatric behavior science: Sinopsis psikiatri: ilmu pengetahuan perilaku psikiatri klinis. (edisi ketujuh). Jilid 2. Widjaja Kusuma (terj.) 1997. Jakarta: Binarupa Aksara.

Lemstra, Mark., Rogers, Maria. et al. 2013. Risk indicators of suicide ideation among on-reserve first nation youth. paediatr child health. 18 (1):15-20. 
McGee, Rob., Williams, Sheila., Nada-Raja, Shyamala. 2005. Is cigarette smoking associated with suicidal ideation among youth people. Am J Psychiatry. 162:619-620.

Miller, Ivan W., Norman, William H. et al. 1991. The modified scale for suicide ideation. Rhode Island: Department of Psychiatry and Human Behavior Brown University and Butler Hospital

Najah, Kamalia. 2013. Pengaruh dukungan sosial dan spiritualitas terhadap simtom depresi pada santri baru di pesantren $\mathrm{Al}$ Hamidiyah Depok. Skripsi Fakultas Psikologi Universitas Islam Negeri Jakarta.

Park, Hyun Sook., Koo, Hyun Young. et al. 2005. Predictors of suicide ideation for adolescents by gender. Journal of Korean academy of nursing 35 (8), 1433-1442.

Pettit, J.W., Joiner, T.E. 2006. Chronic depression: interpersonal sources, therapeutic solutions. Arlington: American Psychological Association.

Subandi. M. A., Rochmawati. Ida., Hamsyah. Fuad. 2011. 'Pulung gantung' A cultural belief of suicidal behavior in Gunungkidul, Yogyakarta, Indonesia. Paper presented at the International conference on Integrating Cultural perspective in the Understanding and Prevention of Suicide, Beijing, 13-17 September 2011.

Sugawara, Norio., Yasui-Fukukori, Norio. et al. 2012. Gender differences in factors associated with suicidal ideation and depressive symptoms among middle-aged workers in Japan. Industrial Health. 2013. 51, 202-213.

Suryomentaram, Grangsang. 1989. Kawruh jiwa/Wejanganipun Ki Ageng Suryomentaram. Jakarta: Haji Mas Agung.

Suseno, Franz Magnis. 1984. Etika jawa. Gramedia Pustaka Utama 
Tri Hariyono

Van Orden, Kimberly. 2009. Construct validity of the interpersonal needs questionnaire. Thesis Florida State University.

Van Orden, Kimberly., Witte, Tracy. et al. 2010. The interpersonal theory of suicide. American psychological association psychological review DOI: 10.1037/a0018697.

Wong, Y. Joel., Tran, Kimberly K. et al. 2011. Asian american college students' suicide ideation: a mixed-methods study. journal of counseling psychology. 58 (2), 197-209 DOI:10.1037/a0023040

World Health Organization. 2007. global school-based student health survey (GSHS). Diunduh dari http://www.who.org

Kedaulatan

Rakyat

(2013).

http://krjogja.com/read/140707/urbanisasi-di-gunungkidul-

tetap-tinggi.kr 